\title{
HYDRAULIC AND STATISTICAL GRAIN-SIZE PARAMETERS OF PINDOS TURBIDITE DEPOSITS
}

\author{
G. Ananiadis, I. Vakalas, N. Kontopoulos and A. Zelilidis \\ Laboratory of Sedimentology, Department of Geology, University of Patras, 26500, Rio, Greece, \\ gananiad@upatras.gr,.jvakalas@upatras.gr,kontopou@upatras.gr, a.zelilidis@upatras.gr
}

\begin{abstract}
Final closure of the Pindos ocean, resulted in collision of Apulia with Pelagonian microplates, produced voluminous clastic sediments that flowed southwards as turbidity currents in the form of submarine fans, giving rise to Pindos flysch during early Tertiary. Samples coming from thinbedded sandstones were collected from five cross-sections throughout Pindos flysch in order to determine the characteristics of the turbidity current between different areas. The hydraulic and grainsize statistical parameters showed that low energy turbidity currents deposited the analyzed sediments. Almost all sampies show a positive skewness due to the competency of the unidirectional flow of the transporting media, where the coarse end of the size frequency curve is "chopped off'. The kurtosis values in combination with the sorting values are plotted to the turbidity filed. A correlation between the mean palaeoflow velocity and the grain size showed that the mean palaeoflow velocities related to sandy silt samples whereas the higher velocities with sandy samples.
\end{abstract}

\section{INTRODUCTION}

In order to estimate the statistical and hydraulic parameters of turbidites from Pindos flysch, sandstone samples were collected from five cross-sections selected throughout the study area (figure 1). In the northern part samples were selected from the cross-sections A-A' (Votonosi-Metsovo) and B-B' (Milia) in Metsovo area, in the northern and central part from the cross-section C-C' in Kastanea area, in the central part samples were selected from cross-section D-D' (Fournas) in Karpenisi-Fournas area and finally in the southern part cross-section E-E' in Nafpaktos-Lidoriki area. Overall, 62 samples were collected.

\section{METHOD}

The collected sandstone samples had an average thickness of $15 \mathrm{~cm}$ in order to compare the results between different areas. In addition, all the samples were characterized by the presence of the subdivision Ta of Bouma sequence, while in small percentage (19\%) subdivisions Tb and Tc were present. Firstly, the samples were crushed in small pieces (approximately $1 \mathrm{~cm}$ long) and dissolved using acetic acid $(30 \% \mathrm{p} / \mathrm{v})$. Furthermore, at the dissolved samples were added Perydrol $(30 \% \mathrm{p} / \mathrm{v})$ and let to dry at $70^{\circ} \mathrm{C}$. After drying, sieve analysis of the samples was followed using the method of sieves and pipette where it was necessary. Using this methodology, 29 samples remained unbroken, with the majority of them coming from Lidoriki area (13 samples) and less from the other areas (Fournas: 8 samples, Kastanea: 6 sampes, Metsovo: 1 sample and Milea: 1 sample). This might be due to the great percentage of quartz in the matrix of the samples.

\section{CLASSIFICATION OF SAMPLES}

For the classification of the samples, we used the classification of Folk, Andrews and Lewis (1970) (fig. 2). Thus, the more fine-grained samples were those of Metsovo (sandy silt and silty sand), Milea (muddy sand and silty sand) and Lidoriki areas (silty sand). In contrast, the coarser samples were those of Kastanea and Fournas areas (sand and silty sand). 


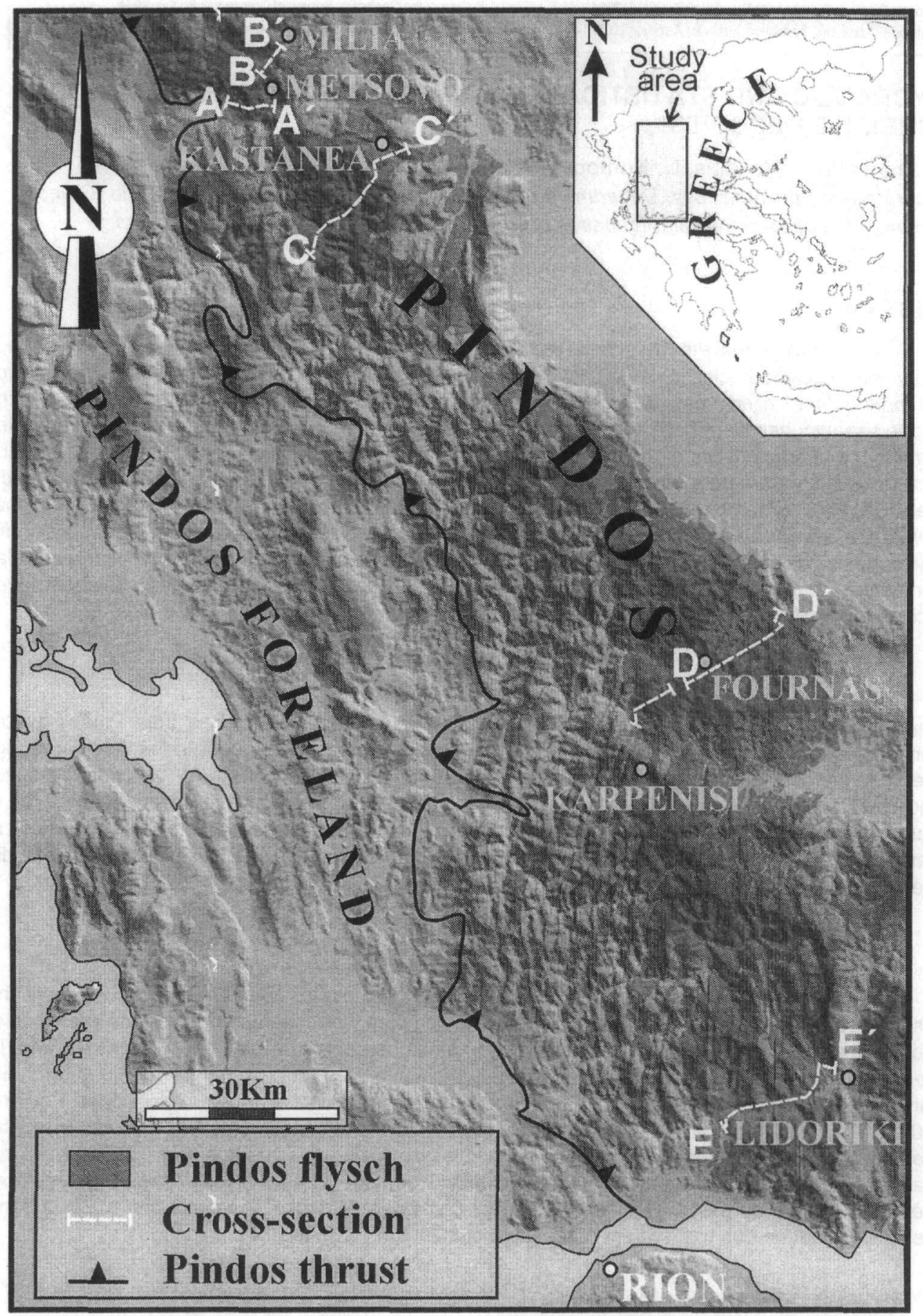

Figure 1. Simplified geological map showing the studied cross-sections. 

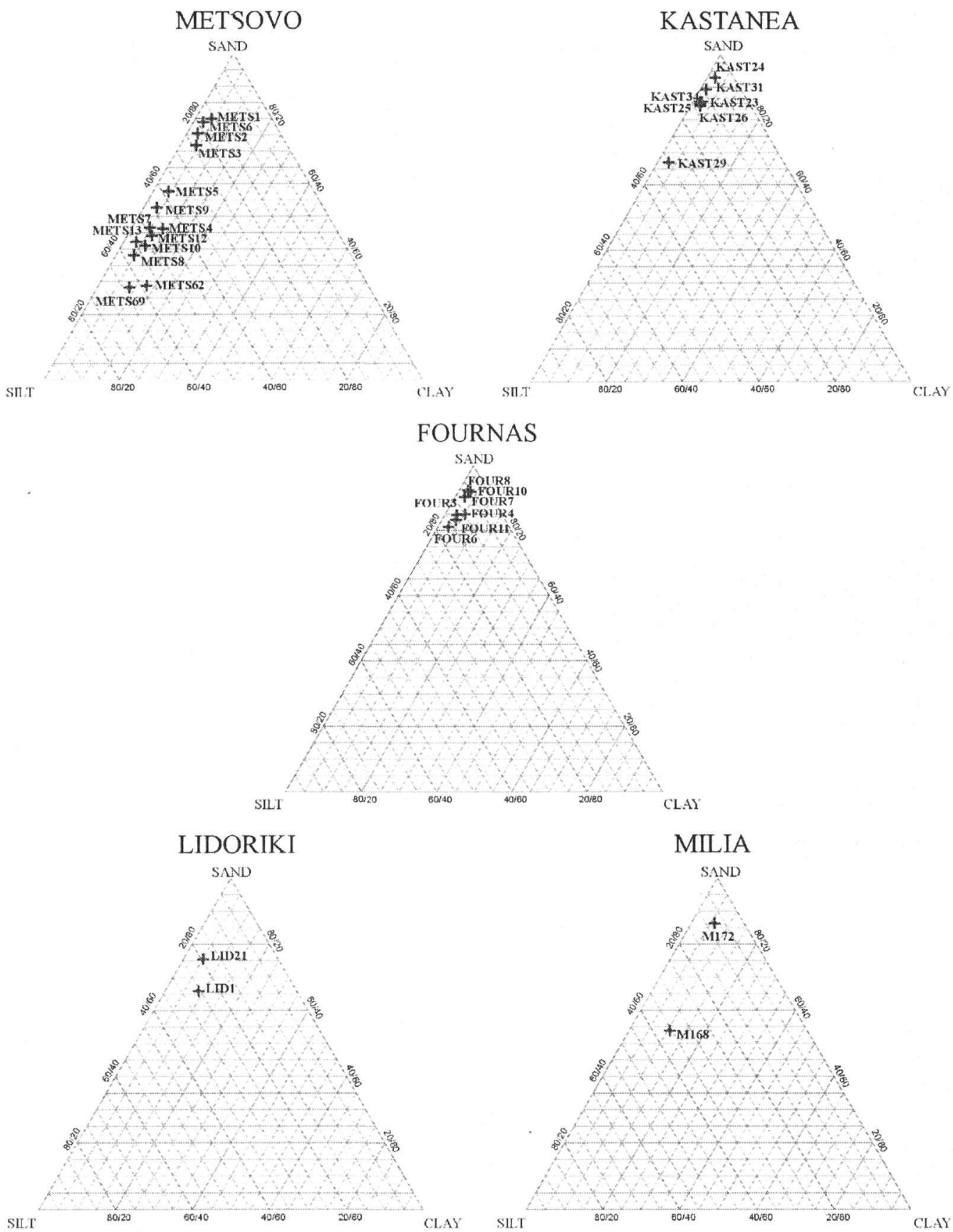

Figure 2. Projection of samples from the studied cross-sections in sand-silt-clay diagram.

\section{STATISTICAL GRAIN-SIZE PARAMETERS}

The estimation of the statistical grain-size parameters (tables 1-5) was accomplished using the mathematic formulas of Folk \& Ward (1957). In detail the results for each area are: 


\section{Cross-section A-A' (Votonosi-Metsovo)}

Table 1. Grain-size statistical parameters of the samples from cross-section A-A'.

\begin{tabular}{|c|c|c|c|c|c|}
\hline Sample & Median & Mean size & Sorting & Skewness & Kurtosis \\
\hline METS1 & 3,62 & 3,47 & 1,35 & 0,00 & 2,00 \\
\hline METS2 & 2,91 & 3,12 & 1,32 & 0,30 & 0,99 \\
\hline METS3 & 3,27 & 3,45 & 1,45 & 0,26 & 1,15 \\
\hline METS62 & 4,63 & 5,04 & 2,21 & 0,46 & 1,92 \\
\hline METS4 & 4,17 & 4,31 & 1,65 & 0,27 & 1,30 \\
\hline METS5 & 3,83 & 3,93 & 1,44 & 0,17 & 1,04 \\
\hline METS6 & 2,95 & 3,10 & 1,29 & 0,24 & 1,13 \\
\hline METS7 & 4,11 & 4,19 & 1,33 & 0,17 & 1,21 \\
\hline METS 8 & 4,39 & 4,37 & 1,03 & $-0,05$ & 0,92 \\
\hline METS9 & 3,92 & 3,81 & 1,46 & $-0,04$ & 1,00 \\
\hline METS10 & 4,31 & 4,41 & 1,41 & 0,18 & 1,23 \\
\hline METS69 & 4,62 & 4,85 & 1,89 & 0,35 & 1,85 \\
\hline METS12 & 4,22 & 4,30 & 1,41 & 0,16 & 1,26 \\
\hline METS13 & 4,25 & 4,28 & 1,26 & 0,08 & 0,99 \\
\hline
\end{tabular}

\section{Cross-section B-B' (Milea)}

Table 2. Grain-size statistical parameters of the samples from cross-section B-B'.

\begin{tabular}{|c|c|c|c|c|c|}
\hline Sample & Median & Mean size & Sorting & Skewuess & Kurtosis \\
\hline M168 & 3,93 & 4,32 & 2,28 & 0,46 & 1,92 \\
\hline M172 & 2,40 & 2,65 & 1,51 & 0,52 & 2,24 \\
\hline
\end{tabular}

\section{Cross-section C-C' (Kastanea)}

Table 3. Grain-size statistical parameters of the samples from cross-section C-C'.

\begin{tabular}{|c|c|c|c|c|c|}
\hline Sample & Median & Mean size & Sorting & Skewness & Kurtosis \\
\hline KAST34 & 2,46 & 2,66 & 1,21 & 0,33 & 1,11 \\
\hline KAST31 & 1,87 & 2,12 & 1,43 & 0,30 & 1,25 \\
\hline KAST29 & 3,35 & 3,60 & 1,49 & 0,33 & 1,03 \\
\hline KAST26 & 2,57 & 2,83 & 1,27 & 0,48 & 1,31 \\
\hline KAST25 & 2,40 & 2,66 & 1,28 & 0,44 & 1,21 \\
\hline KAST24 & 2,18 & 2,33 & 0,94 & 0,37 & 1,30 \\
\hline
\end{tabular}

\section{Cross-section D-D' (Fournas)}

Table 4. Grain-size statistical parameters of the samples from cross-section D-D'.

\begin{tabular}{|c|c|c|c|c|c|}
\hline Sample & Median & Mean size & Sorting & Skewness & Kurtosis \\
\hline FOUR3 & 2,97 & 3,06 & 1,21 & 0,26 & 1,25 \\
\hline FOUR4 & 2,94 & 3,05 & 1,42 & 0,37 & 1,69 \\
\hline FOUR6 & 2,85 & 3,09 & 1,50 & 0,46 & 1,60 \\
\hline FOUR7 & 3,54 & 3,31 & 0,72 & $-0,49$ & 0,97 \\
\hline FOUR8 & 2,79 & 2,78 & 0,93 & $-0,05$ & 0,76 \\
\hline FOUR10 & 2,81 & 2,83 & 0,86 & 0,00 & 0,85 \\
\hline FOUR11 & 3,16 & 3,27 & 1,13 & 0,29 & 1,42 \\
\hline
\end{tabular}

\section{Cross-section E-E' (Lidoriki)}

Table 5. Grain-size statistical parameters of the samples from cross-section E-E'.

\begin{tabular}{|c|c|c|c|c|c|}
\hline Sample & Median & Mean size & Sorting & Skewness & Kurtosis \\
\hline LID1 & 1,81 & 1,81 & 2,04 & 0,34 & 1,47 \\
\hline LID21 & 3,33 & 3,31 & 1,81 & 0,11 & 1,35 \\
\hline
\end{tabular}


Afterwards, diagrams of the alternations in sorting, skewness and kurtosis are displayed in relation with the position of the samples on every cross-section.

According to these tables we are resulted in following:

Mean size: The Mz of the Votonosi-Metsovo samples ranges from 3,12 $\phi$ to $5,04 \phi$ (on the average $4,05 \phi$ ). The Mz of the Milea samples varies between 2,65 $\phi$ and 4,32 $\phi$ (on the average $3,49 \phi$ ). The $M z$ of the Kastanea samples ranges from 2,12 to $3,60 \phi$ (on the average 2,7 $\phi$ ). The Mz of Fournas samples varies between $2,78 \phi$ and $3,31 \phi$ (on the average 3,06 $\phi$ ). The $\mathrm{Mz}$ of the Lidoriki samples ranges from 1,81 to $3,31 \phi$ (on the average 2,57 $\phi$ ).

Standard deviation/sorting: The $\sigma 1$ of Votonosi-Metsovo samples averages $1,46 \phi(1,03 \phi$ to $2,21 \phi)$. The $\sigma 1$ of Milea samples averages $1,90 \phi(1,51 \phi$ to $2,28 \phi)$. The $\sigma 1$ of Kastanea samples averages $1,11 \phi(0,72 \phi$ to $1,50 \phi)$. The $\sigma 1$ of Lidoriki samples averages $1,93 \phi(1,81 \phi$ to $2,04 \phi)$. The Votonosi-Metsovo, Milea and Lidoriki sediments are characterized as poorly to very poorly sorted. Therefore, this result in combination with the presence of little clay suggests a submature texture of sediments (Folk, 1974). The Kastanea and Fournas sediments are characterized as moderately to poorly sorted and in combination to the presence of little clay they show a less submature character.

Skewness: The $\mathrm{Sk}_{\mathrm{I}}$ of Votonosi-Metsovo samples ranges from $-0,05$ to 0,46 (on the average 0,18 ). The $\mathrm{Sk}_{\mathrm{I}}$ of the Milea samples varies from 0,46 to 0,52 (on the average 0,49 ). The $\mathrm{Sk}_{\mathrm{I}}$ of the Kastanea samples ranges from 0,30 to 0,48 (on the average 0,38 ). The $S k_{I}$ of the Fournas samples ranges from $-0,49$ to 0,46 (on the average 0,12 ). The $S_{k_{I}}$ of the Lidoriki samples varies from 0,11 to 0,34 (on the average 0,23 ). The Votonosi-Metsovo sediments are near-symmetrical to strongly fine-skewed, the Milea and Kastanea sediments strongly fine-skewed, the Fournas sediments strongly coarse to strongly fine-skewed and the Lidoriki sediments fine to strongly fineskewed.

Kurtosis: The $\mathrm{K}_{G}$ of the Votonosi-Metsovo sediments ranges from 0,92 to 2,00 (on the average 1,29 ). The $K_{G}$ of the Milea sediments varies from 1,92 to 2,24 (on the average 2,08 ). The $K_{G}$ of the Kastanea sediments ranges from 1,03 to 1,31 (on the average 1,20). The $K_{G}$ of the Fournas sediments varies from 0,76 to 1,69 (on the average 1,22 ). The $K_{G}$ of the Lidoriki samples ranges from 1,35 to 1,47 (on the average 1,41). The Votonosi-Metsovo sediments are mesokurtic to very leptokurtic, the Milea sediments very leptokurtic, the Kastanea sediments mesokurtic to leptokurtic, the Fournas sediments platykurtic to very leptokurtic and Lidoriki sediments leptokurtic.

\section{SCATTER DIAGRAMS OF THE STATISTICAL GRAIN-SIZE PARAMETERS}

Data of the statistical grain-size parameters plotted on scatter diagrams in order to evaluate their relationships and their effectiveness in differentiating of the sedimentological behavior between at the study sections (fig. ?).

Figure $3 \mathrm{~A}$ is the plot of graphic mean grain size versus inclusive graphic standard deviation. Low standard deviation values $(<1 \phi)$ characterize the sand class (fig. 2), higher values $(1 \phi-1,5 \phi)$ are associated with the silty sand and sandy silt classes (fig. 2) while the highest values $(>1,5 \phi)$ belong in the muddy class (fig.2). Moreover, the scatter diagram of figure $3 \mathrm{~A}$ does not demonstrate any relationship between mean size and sorting. This suggests a similar process as flood where the river sediment suspension lies down without sorting (Kukal, 1969). Similar character has the turbidity deposits. Turbidites have poor sorting because coarse and fine material gets carried together as mass flow. The plot of graphic mean grain size versus inclusive graphic skewness is displayed in figure $3 \mathrm{~B}$ and gives infirmation regarding the measure of asymmetry. It shows that $19 \%$ of the sediments are near-symmetrical, 39\% are fine-skewed, 39\% are strongly fine-skewed and $3 \%$ are strongly coarse-skewed. Moreover, the positive skewness ( $78 \%$ of samples) is due to the competency of the unidirectional flow of the transporting media where the coarse end of the size frequency curve is "chopped off" (Friedman, 1961, 1962, 1967). Analogous conditions prevail during the turbidite deposition.

The plot of inclusive graphic standard deviation versus inclusive graphic skewness (fig. $3 \mathrm{C}$ ) illustrates that the very poorly sorted sediments $(>2 \phi)$ are strongly fine-skewed, the moderately sorted sediments are near-symmetrical or strongly coarse-skewed and the poorly sorted sediments are fine to strongly fine-skev'ed. The scatter plot shows a turbidite field according to Bjorlykke (1989). 


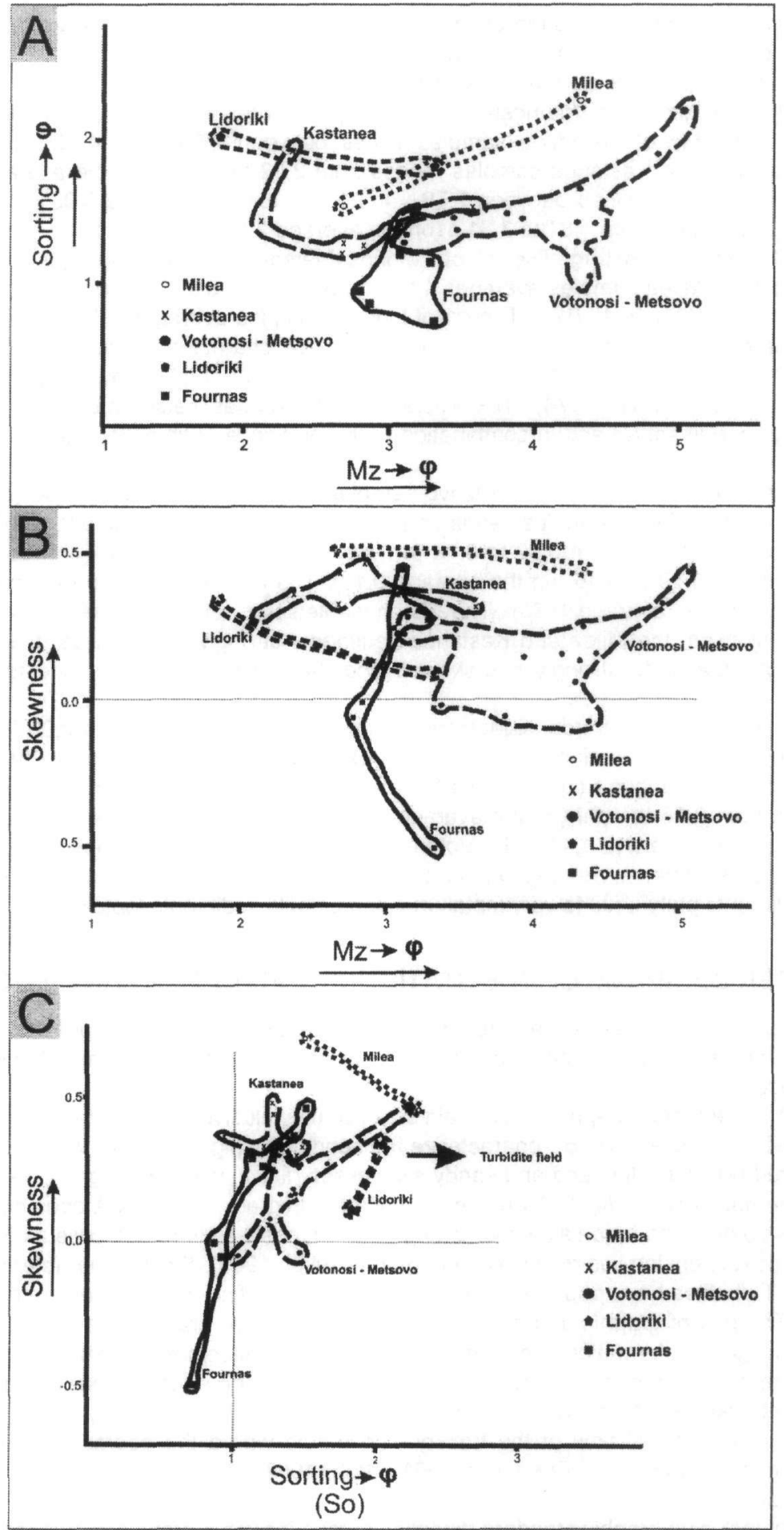

Figure 3: Scatter diagrams of the statistical grain-size parameters. A: Mean size in relation to sorting, B: Mean size in relation to Skewness, and C: Sorting in relation to Skewness. 


\section{HYDRAULIC PARAMETERS}

Using Rubey's (1933) yeneral formula, for settling velocities, we converted diameters of grains $(\mathrm{mm})$, in settling velocity values $(\mathrm{W}$ in $\mathrm{cm} / \mathrm{sec})$. Furthermore, the cumulative curves were constructed, based on the logarithmic scale Psi=- $\log _{2}\left(W_{m}\right)$ of Middleton, (1967) (fig. 6). In order to estimate the mean palaeoflow velocity, at the time of deposition, the Psiso values converted to settling velocities, from the cumulative hydraulic curves and using Middleton (1967) scale. The estimation of the mean flow velocity at the time of deposition, is based on Komar's (1985) hydraulic interpretation of turbidites and it is given by the following equation:

$$
\bar{u}=W m / \sqrt{C f}
$$

Where the $\bar{u}$ is the mean flow velocity at the time of deposition, $W_{m}$ is the settling velocity, which corresponds to 50-percentile, and $\mathrm{C}_{\mathrm{f}}$ is a dimensionless drag coefficient. In the calculations of mean flow velocity, we used $\mathrm{C}_{\mathrm{f}}=0.004$, as proposed by Komar (1985) first.
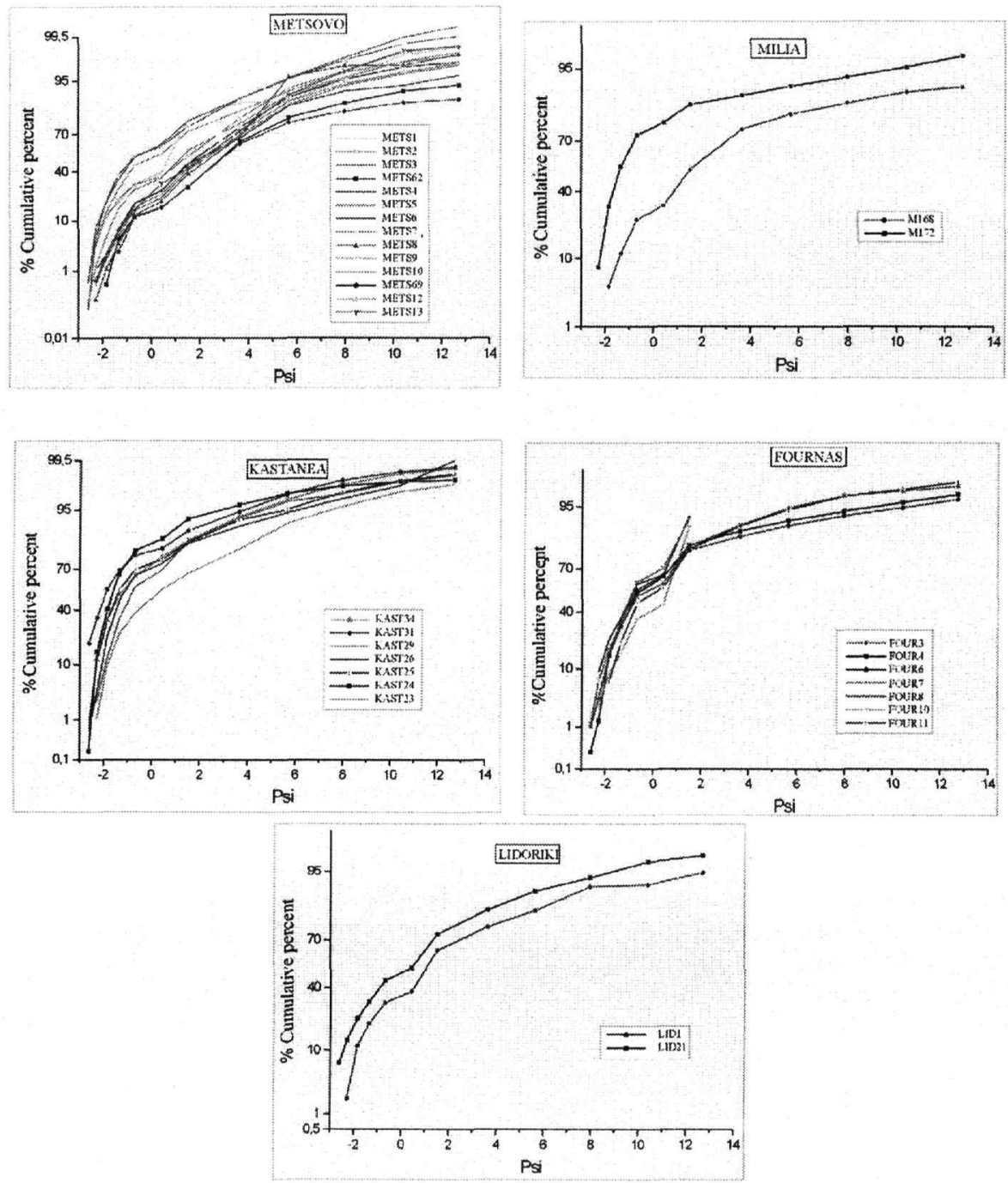

Figure 4. Cumulative curves of settling-velocity (Psi) distributions of samples from the studied cross-sections. 


\section{METSOVO}

Table 6. Hydraulic and lithological parameters of samples from cross-section A-A :

\begin{tabular}{|c|c|c|c|c|}
\hline Sample & $\begin{array}{c}\text { Bed thick- } \\
\text { ness } \\
(\mathrm{cm})\end{array}$ & $\begin{array}{c}\text { Bouma se- } \\
\text { quence }\end{array}$ & $\begin{array}{c}\text { Classification } \\
\text { of sample }\end{array}$ & $\begin{array}{c}\text { Mean flow veloc- } \\
\text { ity } \\
(\mathrm{cm} / \mathrm{sec})\end{array}$ \\
\hline METS1 & 19 & $\mathrm{Ta}$ & Silty sand & 9,75 \\
\hline METS2 & 17 & $\mathrm{Ta}$ & Silty sand & 27,34 \\
\hline METS3 & 11 & $\mathrm{Ta}$ & Silty sand & 17,18 \\
\hline METS62 & 15 & $\mathrm{Ta}$ & Sandy silt & 2,16 \\
\hline METS4 & 30 & $\mathrm{Ta}$ & Sandy silt & 4,24 \\
\hline METS5 & 11 & $\mathrm{Ta}$ & Silty sand & 7,13 \\
\hline METS6 & 10 & $\mathrm{~Tb}, \mathrm{Tc}$ & Silty sand & 25,86 \\
\hline METS7 & 10 & $\mathrm{Ta}$ & Sandv silt & 4,7 \\
\hline METS8 & 14 & $\mathrm{Ta}$ & Sandy silt & 3,12 \\
\hline METS9 & 13 & $\mathrm{Tc}$ & Silty sand & 6,2 \\
\hline METS10 & 14 & $\mathrm{Ta}$ & Sandy silt & 3,49 \\
\hline METS69 & 15 & $\mathrm{Ta}$ & Sandy silt & 2,27 \\
\hline METS12 & 8,5 & $\mathrm{Ta}$ & Sandy silt & 3,98 \\
\hline METS13 & 10 & $\mathrm{Ta}$ & Sandy silt & 3,87 \\
\hline
\end{tabular}

For samples from Metsovo area (table 6), the higher value of mean flow velocity was 27,34 $\mathrm{cm} / \mathrm{sec}$ (METS2), instead the lower value was 2,27 cm/sec (METS69).

MILIA

Table 7. Hyciraulic and lithological parameters of samples from cross-section B-B'.

\begin{tabular}{|c|c|c|c|c|}
\hline Sample & $\begin{array}{c}\text { Bed thickness } \\
(\mathrm{cm})\end{array}$ & Bouma sequence & $\begin{array}{c}\text { Classification } \\
\text { of sample }\end{array}$ & $\begin{array}{c}\text { Mean flow velocity } \\
(\mathrm{cm} / \mathrm{sec})\end{array}$ \\
\hline M168 & 10 & $\mathrm{Ta}$ & Muddy sand & 6,22 \\
\hline M172 & 17 & Ta & Silty sand & 43,32 \\
\hline
\end{tabular}

The average value for Milea samples was $24,77 \mathrm{~cm} / \mathrm{sec}$ (table 7).

KASTANEA

Table 8. Hycraulic and lithological parameters of samples from cross-section C-C'.

\begin{tabular}{|c|c|c|c|c|}
\hline Sample & $\begin{array}{c}\text { Bed thickness } \\
(\mathrm{cm})\end{array}$ & Bouma sequence & $\begin{array}{c}\text { Classification } \\
\text { of sample }\end{array}$ & $\begin{array}{c}\text { Mean flow velocity } \\
(\mathrm{cm} / \mathrm{sec})\end{array}$ \\
\hline KAST34 & 12 & $\mathrm{Ta}$ & Silty sand & 41,52 \\
\hline KAST31 & 11 & $\mathrm{Ta}$ & Sand & 61,52 \\
\hline KAST29 & 9 & $\mathrm{Ta}$ & Silty sand & 14,95 \\
\hline KAST26 & 16 & $\mathrm{Ta}$ & Silty sand & 37,35 \\
\hline KAST25 & 13 & $\mathrm{Ta}$ & Silty sand & 43,41 \\
\hline KAST24 & 11 & $\mathrm{Ta}$ & Sand & 50,23 \\
\hline KAST23 & 13 & $\mathrm{Ta}$ & Silty sand & 29,30 \\
\hline
\end{tabular}

For samples from Kastanea area (table 8), the higher value of mean flow velocity was 61,52 $\mathrm{cm} / \mathrm{sec}$ (KAST31), instead the lower value was $14,95 \mathrm{~cm} / \mathrm{sec}$ (KAST29).

\section{FOURNAS}

Table 9. Hydraulic and lithological parameters of samples from cross-section D-D'.

\begin{tabular}{|c|c|c|c|c|}
\hline Sample & $\begin{array}{c}\text { Bed thick- } \\
\text { ness } \\
(\mathrm{cm})\end{array}$ & $\begin{array}{c}\text { Bouma se- } \\
\text { quence }\end{array}$ & $\begin{array}{c}\text { Classification } \\
\text { of sample }\end{array}$ & $\begin{array}{c}\text { Mean flow veloc- } \\
\text { ity } \\
(\mathrm{cm} / \mathrm{sec})\end{array}$ \\
\hline FOUR3 & 13 & $\mathrm{Ta}$ & Siltv sand & 25,69 \\
\hline FOUR4 & 15 & $\mathrm{Ta}$ & Siltv sand & 26,59 \\
\hline FOUR6 & 15 & $\mathrm{Ta}$ & Siltv sand & 28,5 \\
\hline FOUR7 & 16 & $\mathrm{Ta}, \mathrm{Tb}$ & Sand & 10,65 \\
\hline FOUR8 & 17 & $\mathrm{Ta}$ & Sand & 30,55 \\
\hline FOUR10 & 8 & $\mathrm{Ta}$ & Sand & 29,92 \\
\hline FOUR11 & 16 & $\mathrm{Ta}$ & Silty sand & 19,74 \\
\hline
\end{tabular}


For Fourna samples (table 9), the higher value of mean flow velocity was $30,55 \mathrm{~cm} / \mathrm{sec}$ (FOUR8), while the lower value was $10,65 \mathrm{~cm} / \mathrm{sec}$ (FOUR7).

\section{LIDORIKI}

Table 10. Hydraulic and lithological parameters of samples from cross-section E-E'.

\begin{tabular}{|c|c|c|c|c|}
\hline Sample & $\begin{array}{c}\text { Bed thickness } \\
(\mathrm{cm})\end{array}$ & Bouma sequence & $\begin{array}{c}\text { Classification } \\
\text { of sample }\end{array}$ & $\begin{array}{c}\text { Mean flow velocity } \\
(\mathrm{cm} / \mathrm{sec})\end{array}$ \\
\hline LID1 & 17 & $\mathrm{~Tb}$ & Silty sand & 8,23 \\
\hline LID21 & 19 & $\mathrm{Ta}$ & Silty sand & 15,06 \\
\hline
\end{tabular}

The average value for lidoriki samples was $11,65 \mathrm{~cm} / \mathrm{sec}$ (table 10).

\section{CONCLUDING REMARKS}

Samples from Metsovo (A-A'), Milia (B-B'), Kastanea (C-C') and Lidoriki ( $\left.E-E^{\prime}\right)$ are characterized mainly as poorly sorted to very poorly sorted, while samples from Fournas area (D-D') are characterized as moderately to poorly sorted. This sorting character confirms the presence of subdivition Ta of Bouma sequence and indicates that low energy turbidity currents deposited the analyzed sediments.

Almost all samples show a positive skewness. This value of skewness is due to the competency of the unidirectional flow of the transporting media where the coarse end of the size frequency curve is "chopped off". Analogous conditions prevail during the turbidite deposition.

The most of the samples (68\%) were characterized by leptokurtic to very leptokurtic curves. The remain samples are mesokurtic, except samples FOUR8 and FOUR10 which are platykurtic. The kurtosis values in combination with the sorting values are plotted in the turbidite field according to Bjorlykke (1989).

The mean flow velocity at the time of deposition from samples coming from areas except Kastanea (C- $\left.\mathrm{C}^{\prime}\right)$, ranged from 2.27 to $30 \mathrm{~cm} / \mathrm{sec}$, showing that these turbidites were deposited from sandy low-density turbidity currents (according to Nelson \& Nilsen, 1984, low-density turbidity currents have mean flow velocities lower than $25 \mathrm{~cm} / \mathrm{sec}$ ). On the other hand, samples coming from Kastanea area showed slightly higher mean palaeoflow velocities at the time of deposition ranging from 14.95 to $61.51 \mathrm{~cm} / \mathrm{sec}$ and deposition from higher density sandy turbidity currents than the other areas. Furthermore, a correlation between the mean palaeoflow velocity and the grain size was confirmed. Thus, the lower mean palaeoflow velocities were found on sandy silt samples (cross-section A-A'), while the higher on sand samples (cross-section $\mathrm{C}^{-} \mathrm{C}^{\prime}$ ).

\section{REFERENCES}

Bjorlykke, K. (1989) Sedimentology and Petroleum Geology. Springer-Verlag, New York, 370p.

Kukal, Z. (1971) Geology of Recent Sediments. Academic Press, London, 490p.

Folk R.L. (1974) Petrology of Sedimentary Rocks. Hemphill, Austin, Texas, 182p.

Folk R.L. \& Ward W.C. (1957) Brazos river bar: a study of significante of grain size parameters. J. Sediment. Petrol., 27, 3-26.

Folk, R.L., Andrews, P. B. \& Lewis, D. W. (1970) Detrital sedimentary rock classification and nomenclature for use in New Zealand, New Zealand Jour. Geology and Geophysics, 13, 937-968.

Friedman, G.M. (1961) Distribution between dune, bech and river sands from their textural characteristics. J.Sed.Petr., 31, 514-529.

Friedman, G.M. (1962) On sorting, sorting coeflicients, and the lognormality of the grain-size distribution of sandstones. J. Geoll., T0, 737-753.

Friedman, G.M. (1979) Differences in size distributions of populations of particles among sands of varions origins: Addendum to IAS Presidential Address. Sedimentology, 26, 859-862.

Friedman, G.M. (1967) Dynamic processes and statistical parameters for size frequency distribution of beach and river sands. Jour. Sedimentary Petrology, 37, 327-354.

Rubey, W.W. (1933) Settling velocity of gravel, sand, and silt particles. Am. Jour. Sci., 25, 325-338.

Middleton, G.V. (1967) Experiments on density and turbidity currents. III. Deposition of sediments. Can. J. Earth Sc., $4,475-505$. 
Komar, P. D. (1985) The hydraulic interpretation of turbidites from their grain sizes and sedimentary structures. Sedimentology, 32, 395-407.

Nelson, C.H. \& Nilsen, T.H. (1984) Modern and ancient deep-sea fan sedimentation. Soc. Econ. Paleontol. Mineral., Short course, 14. 